\section{Loyalitas Kreativitas \\ Aldi Masyarakat Kreatif}

P-ISSN 2722-2101, E-ISSN 2722-4201

Program Studi Ekonomi Manajemen Universitas Pamulang

Jurnal LOKABMAS Kreatif Vol.02,No.03.Nov2021Hal.14-23

Email:jurnalkreatif.manajemen@gmail.com

\title{
MENANGKAP PELUANG USAHA SAAT PANDEMI COVID-19 DI KARANG TARUNA 022 PONDOK BENDA PAMULANG TANGERANG SELATAN
}

\author{
Ita Darsita, Dana, Sawukir, Ratna Dumilah, Asrida Warni Tanjung \\ Dosen Prodi Manajemen Fakultas Ekonomi Universitas Pamulang \\ Email : dosen02235@unpam.ac.id, dosen02224@unpam.ac.id,dosen02319@unpam.ac.id, \\ dosen02209@unpam.ac.id, dosen02212@unpam.ac.id
}

\begin{abstract}
ABSTRAK
Tujuan dari kegiatan Pengabdian Kepada Masyarakat ini adalah untuk melaksanakan salah satu Tri Dharma Perguruan Tinggi. Selain itu, melalui kegiatan Pengabdian Kepada Masyarakat ini, diharapkan menjadi kesempatan bagi Karang Taruna 022 Pondok Benda Pamulang Tangerang Selatan untuk berdiskusi dengan narasumber terkait dengan menangkap peluang usaha saatpandemic Covid-19. Selain itu diharapkan dengan pengabdian kepada masyarakat ini keberadaan perguruan tinggi dapat memberikan kontribusi besar kepada pengembangan dan penerapan keilmuan kepada masyarakat. Metode kegiatan yang digunakan adalah langsung mendatangi masyarakat di Karang Taruna 022 dengan memberikan penyuluhan dan pelatihan pemanfaatan teknologi dalam Menangkap Peluang Usaha Saat Pandemi Covid-19. Hasil kegiatan Pengabdian Kepada Masyarakat ini adalah bertambahnya keilmuan dan keterampilan di Karang Taruna 022 Pondok Benda, khususnya di bidang SDM yaitu menagkap peluang usaha saat pandemicCovid-19.Ilmu yang didapatkan pada kegiatan Pengabdian Kepada Masyarakat ini diharapkan mampu memberikan semangat dalam menyampaikan pengetahuan dan pelatihan dalam memberikan motivasi serta berkontribusi bagi generasi muda, baik di lingkungan kampus maupun masyarakat.
\end{abstract}

\section{Kata kunci : Peluang Usaha, Pandemi Covid-19}

\section{ABSTRACT}

The purpose of this Community Service activity is to implement one of the Tri Dharma of Higher Education. In addition, through this Community Service activity, it is hoped that it will be an opportunity for Karang Taruna 022 Pondok Benda Pamulang, South Tangerang to discuss with resource persons related to capturing business opportunities during the Covid-19 pandemic. In addition, it is hoped that with this community service, the existence of universities can make a major contribution to the development and application of science to the community. The method of activity used is to go directly to the community in Karang Taruna 022 by providing counseling and training on the use of technology in Capturing Business Opportunities During the Covid-19 Pandemic. The result of this Community Service activity is the increase in knowledge and skills at Karang Taruna 022 Pondok Benda, especially in the field of HR, namely capturing business opportunities during the Covid-19 pandemic. The knowledge gained in this Community Service activity is expected to be able to provide enthusiasm in conveying knowledge and training in provide motivation and contribute to the younger generation, both in the campus environment and the community.

Keywords: Business Opportunities, Covid-19 Pandemic 
Loyalitas Kreativitas

Aldi Masyarakat Kreatif
P-ISSN 2722-2101, E-ISSN 2722-4201

Program Studi Ekonomi Manajemen Universitas Pamulang

Jurnal LOKABMAS Kreatif Vol.02,No.03.Nov2021Hal.14-23

Email:jurnalkreatif.manajemen@gmail.com

\section{PENDAHULUAN}

Sebagai organisasi sosial kepemudaan Karang Taruna merupakan wadah atau tempat pembinaan dan pengembangan dalam upaya mengembangkan kegiatan ekonomi, sosial, budaya dengan pemanfaatan semua potensi yang ada dilingkungan masyarakat baik sumber daya manusia atau sumber daya alam itu sendiri yang telah tersedia.Seperti dalam bidang ekonomi, olahraga, keterampilan, keagamaan dan kesenian sesuai dengan tujuan didirikannya karang taruna untuk memberikan pembinaan dan pemberdayaan kepada para remaja yang ada di dalam suatu desa atau wilayah itu sendiri.

Peluang usaha adalah sebuah kesempatan yang akan didapatkan oleh orang demi mendapatkan tujuan dengan cara melakukan sebuah usaha yang akan memanfaatkan berbagai macam sumber daya yang akan dimiliki. Dalam hal ini peluang usaha menjadi hal yang akan paling penting untuk dilakukan sebelum membuka sebuah bisnis. Dalam dunia usaha yang telah berkembang pesat dari tahun ke tahun ini, daya saing semakin tinggi. Hal ini dipicu oleh semakin berkembangnya kebutuhan akan barang dan jasa.

Peluang usaha yang mempunyai potensial tinggi adalah bersumber dari diri sendiri, seperti dari hobi, keahlian pengetahuan dan dari riset atau pengamatan lingkungan. Alasan mengapa peluang yang baik datang dari diri sendiri karena Untuk menjalankan usaha haruslah konsisten dan memiliki komitmen.

Untuk menjalankan usaha memerlukan proses yang panjang, sampai usaha tersebut sukses Untuk menjalankan usaha butuh terus mencoba dan pantang menyerah, dengan didukung kreativitas dan juga mempunyai pengetahuan yang mencukup untuk meraih keberhasilan. Dari lingkungan terdapat banyak sumber peluang usaha yang diperoleh dari lingkungan sekitar, seperti usaha yang dimiliki orang tua yang terus dikembangkan, menjadikan semakin besar dan luas, di lingkungan sekitar rumah dan kebiasaan diri sendiri.Dari konsumen seperti permintaan, keluhan, saran atau harapan konsumen pada barang atau jasa di pasar dapat menjadi sumber ide untuk menciptakan usaha.

Dari perubahan yang terjadi peluang usaha bisa muncul dari berbagai perubahan lingkungan apabila orang tersebut dapat membaca situasi untuk dijadikan peluang usaha.Seperti berbisnis secara online, ketika berbisnis online ternyata sangat menjanjikan asal terus berusaha, selalu melakukan inovasi dan bisa bersaing dengan banyak penjual di pasaran. Bisnis online yang bisa ditekuni adalah seperti makanan, jual smartphone atau kamera dan yang sampai kapanpun akan tren adalah menjual pakaian atau fashion dan juga aksesories.

Pandemi COVID-19 di Indonesia merupakan bagian dari pandemi penyakit koronavirus 2019 (COVID-19) yang sedang berlangsung di seluruh dunia. Penyakit ini disebabkan oleh koronavirus sindrom pernapasan akut berat 2 (SARS-CoV-2). Kasus positif COVID-19 di Indonesia pertama kali dideteksi pada tanggal 2 Maret 2020, ketika dua orang terkonfirmasi tertular dari seorang warga negara Jepang. Pada tanggal 9 April, pandemi sudah menyebar ke 34 provinsi dengan DKI Jakarta, Jawa Barat dan Jawa Tengah sebagai provinsi paling terpapar virus corona di Indonesia. Sampai tanggal 15 Maret 2021, Indonesia telah melaporkan 1.425.044 kasus positif menempati peringkat pertama terbanyak di Asia Tenggara.

Pandemi covid 19 berimbas pada perekonomian masyarakat, terutama usaha kecil dan menengah yang rentan berkurang pendapatannya. Namun, di tengah wabah covid 19 , banyak peluang untuk usaha online seperti menjual makanan, masker, ramuan herbal dan Hand Sanitizaer dan lain sebagai nya. Berbisnis secara online juga masih banyak strategi agar kita mampu mencapai target hingga keuntungan yang diinginkan. Selain strategi, rasa percaya diri dan pantang menyerah pun menjadi kunci bagi kita, untuk meraih kesuksesan berbisnis secara online.

Ada banyak cara untuk memulai bisnis secara online hingga memberikan 
keuntungan yang fantastis meski kita termasuk pemula. Maka dari itu, tidak ada kata terlambat bagi kita yang ingin memulai berbisnis.Selain itu, ciptakan identitas merek kuat, manfaatkan jejaring sosial untuk menjaring ide baru dan memberikan penawaran, serta berkomitmen untuk menindaklanjuti rencana yang sudah disusun.Melalui pemanfaatan teknologi sebagai media kita dapat meningkatkan mutu jualan online.

Perkembangan teknologi informasi yang sangat cepat termasuk internet ternyata memberi dampak yang besar bagi seluruh aspek yang ada, tidak terkecuali perkembangan pada dunia bisnis dan pemasaran.Dengan berkembangnya tekhnologi yang cepat membuat banyak orang menggunakan tekhnologi itu untuk melakukan transaksi jual beli menggunakan internet.Hal ini tidak aneh mengingat jumlah pengguna internet yang terus bertumbuh pesat dapat menjadi sebuah pasar yang potensial untuk dimasuki para pebisnis dan aktualisasi belanja yang terjadi sangat cepat, nyaman, serta dilakukan di mana saja dan kapan saja.Pertumbuhan pengguna internet semakin pesat seiring semakin majunya teknologi.

Dampak yang seperti itu juga berpengaruh dalam dunia usaha yang semakin marak di era globalisasi ini dan ketatnya persaingan bisnis.Dengan majunya teknologi internet juga dapat menjadi sarana dalam melakukan transaksi jual-beli.Pada masa sekarang ini internet bisa diakses di mana saja dan kapan saja.Hal ini dikarenakan banyaknya akses yang memungkinkan untuk menggunakan internet.Internet sudah menjadi kebiasaan yang membuat kita menjadi lebih maju dan modern.Akses yang mudah menjadi pendorong untuk menggunakan internet.

\section{Rumusan Masalah}

Berdasarkan permasalahan utama yang dijelaskan pada bab sebelumnya, maka dberikan pengarahan kepada masyarakat Karang Taruna 022 untuk dapat mengetahui pemanfaatan Teknologi dalam Menangkap Peluang Usaha Saat Pandemi Covid-19. Saat ini teknologi informasi bukan hanya berkembang dengan pesat, tetapi juga sering mengalami perubahan yang sangat cepat. Hampir setiap detik selalu ditemukan penemuan baru dengan tujuan untuk memperbaiki atau menyempurnakan hasil teknologi sebelumnya. manfaat teknologi iformasi pada saat ini tidak hanya dipergunakan untuk kepentingan organisasi saja, tetapi juga untuk kebutuhan individu. Bagi organisasi teknologi informasi dapat digunakan untuk mencapai keunggulan kompetitif, sedangkan untuk kebutuhan individu, teknologi dipergunakan untuk kepentingan pribadi seperti mencari pekerjaan.

Dengan kemajuan teknologi yang semakin pesat saat ini, bisa dikatakan teknologi informasi telah memasuki ke segala bidang, salah satunya dibidang bisnis. Bisnis tanpa adanya memanfaatkan teknologi informasi tidak akan bisa maju dan terancam bangkrut. Banyak pelaku bisnis yang memanfaatkan teknologi informasi untuk mendukung kemajuan bisnis dan mendapatkan keuntungan yang diinginkan. Saat ini teknologi informasi bukan hanya berkembang dengan pesat, tetapi juga sering mengalami perubahan yang sangat cepat. Hampir setiap detik selalu ditemukan penemuan baru dengan tujuan untuk memperbaiki atau menyempurnakan hasil teknologi sebelumnya. manfaat teknologi nformasi pada saat ini tidak hanya dipergunakan untuk kepentingan organisasi saja, tetapi juga untuk kebutuhan individu. Bagi organisasi teknologi informasi dapat digunakan untuk mencapai keunggulan kompetitif, sedangkan untuk kebutuhan individu, teknologi dipergunakan untuk kepentingan pribadiseperti mencari pekerjaan.

Jadi peran perkembangan teknologi informasi pada saat ini tidak bisa dipisahkan dari dunia bisnis, karena perkembangan teknologi informasi dapat memberikan berbagai keuntungan dan kemudahan dalam menjalankan aktivitas bisnis.Namun selain memberikan manfaat dalam bidang bisnis, teknologi infromasi juga dapat disalah gunakan dalam hal yang kurang baik. Oleh 
karen itu, untuk pengunaannya harus digunakan secara bijak.

Dengan mempertimbangkan latar belakang yang telah dijelaskan diatas kami berinisiatif untuk membentuk Pengabdian Kepada Masyarakat di Karang Taruna khususnya dalam program pelatihan agar dalam Menangkap Peluang Usaha Saat Pandemi Covid-19 di Karang Taruna 022.

\section{Tujuan Kegiatan}

Adapun tujuan dan mamfaat dari kegiatanPengabdian Kepada Masyarkat ini adalah agar masyarakat khususnya di Karang Taruna 022 mampu dalam pemanfaatan teknologi dalam berbisnis online diantaranya :

1. Dapat meningkatkan pengetahuan teknologi dalam bisnis online di Karang Taruna 022.

2. Dapat meningkatkan perekonomian khususnya di Karang Taruna 022.

\section{TINJAUAN PUSTAKA}

\section{Peluang Usaha}

Menurut (Hendro dan Chandra, 2006, p.149) peluang adalah suatu keadaan di setiap saat kehidupan kita sehari-hari, baik sejak bangun pagi hingga larut malam. Peluang dapat muncul dalam berbagai bentuk, tergantung cara kita melihatnya. Yang terpenting adalah bukan sekedar cara melihat atau memandang suatu hal, melainkan bagaimana sesuatu ketidaksempurnaan itu dapat berubah menjadi peluang yang sebenarnya dibutuhkan oleh pasar.

Peluang akan menjadi peluang yang prospektif bila mengandung unsure-unsur sebagai berikut:

1. Sedang dibutuhkan oleh pasar

2. Memecahkan kesulitan atau masalah yang sedang dihadapi pasar

3. Menyempurnakan yang sebelumnya

4. Benar-benar beda dan memiliki nilai tambah

5. Temuan yang orisinil (inovatif)

6. Memberi keuntungan yang nyata
7. Ada unsur yang dibanggakan oleh pembeli

8. Dapat diwujudkan

Menurut (Hendro dan Chandra, 2006, p.153) konsep untuk memudahkan didalam menemukan dan menciptakan peluang cukup sedehana, yaitu:

1. Awali dengan melihat sesuatu dengan "teori ketidaksempurnaan", bahwa apa yang dilihat adalah tidak sempurna. Oleh karena itu ada peluang untuk menyempurnakannya

2. Gunakan inspirasi, bahwa peluang itu adalah:

a. Merebut pasar dari pesaing (intersection)

b. Menggantikan posisi yang ada dari pesaing (replacement)

c. Mengisi kekosongan dari celah persaingan (filter)

d. Menghancurkan market leader (destroyer)

e. Melengkapi ketidaksempurnaan pasar (compatible)

3. Setelah menemukan beberapa alternartif peluang, maka buatlah daftar peluang itu

4. Memilih peluang yang berpotensi (maksimal 3)

5. Jadikan peluang yang pertama sebagai peluang yang paling berpotensi

6. Buatlah suatu tulisan, sehingga kita dapat selalu melihatnya

7. Tambahkan kata-kata yang dapat memotifasi

8. Mulailah mengambil keputusan yang "smart" tanpa harus menjadi seorangrisk taker

9. Jangan takut untuk mencoba

10. Ciptakanlah kesuksesan-kesuksesan kecil terlebih dahulu untuk meningkatkan rasa percaya diri dan terus berkreasi, berinovasi, dan bertahan.

Banyak orang beranggapan bahwa tidak semua orang dapat peka terhadap peluang.Ada beberapa orang yang dapat peka terhadap peluang, ada juga yang tidak.Namun anggapan tersebut tidaklah benar, karena kepekaan dalam mengenali peluang tergantung dari daya imajinasi seseorang yang membuatnya mampu 
Loyalitas Kreativitas

Aldi Masyarakat Kreatif
P-ISSN 2722-2101, E-ISSN 2722-4201

Program Studi Ekonomi Manajemen Universitas Pamulang

Jurnal LOKABMAS Kreatif Vol.02,No.03.Nov2021Hal.14-23

Email:jurnalkreatif.manajemen@gmail.com melihat sesuatu dari sisi positif.Itulah bukti bahwa dengan merubah negative thinking menjadi positive thinking dapat memberikan peluang baru (bagaimana memanfaatkannya dan bukan membuangnya).

Menurut (Jackie Ambadar, dkk, 2007, p.53) ada dua format yang mungkin dilakukan seseorang dalam usahanya mengenali peluang, yaitu:

a. See - Do - Get, dimana seseorang yang melihat (see) peluang untuk dilaksanakan (do) menjadi bisnis (get) yang menguntungkan (profit / sukses).

b. Do - See - Get, dimana seseorang terlibat (do) dalam suatu bisnis, kemudian menemukan (see) peluang bisnis baru (get) yang menguntungkan.

Menurut (Jackie Ambadar, dkk, 2007, p.65), dalam mengelola peluang dibutuhkan kelebihan seseorang dari sisi mental (berani bertindak), pengetahuan (melaksanakan jadi produk/ bisnis), dan adanya fasilitas pendukung (modal, peralatan dan sumberdaya lain).

Banyak pengusaha di Indonesia yang pandai "mencari" peluang, tetapi gagal dalam pengembangan bisnisnya lebih lanjut.Bila berhasil mengembangkan, kemudian gagal untuk mempertahankanya. Tidak sedikit pula perusahaan yang hanya berumur pendek, mati muda atau bahkan pindah tangan ke orang lain. Hal tersebut tentunya sangat merugikan.Sikap pantang menyerah dan putus asa merupakan kunci sukses bagi para pengusaha yang sedang tidak dalam keadaan tersudut.

Menurut mereka, kendala yang menghadang jalan bisnis hendaknya jangan dipandang sebagai penghalang.Namun sebaliknya, perlu dilihat sebagai ujian. Kegagalan awal akan menjadi rintangan pertama yang menghalanga dalam menempuh jenjang demi jenjang tangga sukses. Namun, dengan kerja keras dan semangat pantang putus asa, tentunya rintangan yang mengahadang jalan dapat dihadapi dengan mudah.

Menurut (Jackie Ambadar, dkk, 2007, p.88), ada beberapa tips dalam mengelola peluang:

1. Memulai (perlu keberanian menghadapi risiko gagal)

2. Mengembangkan (perlu kekuatan pendorong menjadi lebih besar)

3. Mempertahankan (daya tahan untuk tetap fit)

Menurut (Hendro dan Chandra, 2006, p.155) setelah menemukan, menciptakan, dan memulai memanfaatkan peluang tersebut, sebaiknya tidak berhenti pada titk itu saja. Namun, tingkatkan lah nilai tambahnya dengan cara:

1. Make it better than (Membuatnya lebih baik), tingkatkanlah kesempatan yang ada dan tambahkan "added value" dan fitur- fitur yang lebih baik

2. Make it "really different" (Membuat dengan cara yang sangat berbeda), fungsi produk yang diciptakan boleh sama dengan yang lain, tetapi segala sesuatunya harus berbeda, baik dari segi positioning, packaging, persepsi, dan lain sebagainya

3. Better to innovate than meet too (Selalu melakukan inovasi dari pada menjiplak produk orang lain), lebih baik berinovasi dari pada menjiplak produk orang lain. Namun, akan lebih tidak baik lagi jika tidak memanfaatkan peluang yang ada

4. Make your opportunity is unique (Membuat peluang yang unik), membuat peluang bisnis menjadi benarbenar unik dan tidak ada duanya. Tidak hanya berbeda (different), melainkan harus memiliki cirri khas

5. Make your skill specialist (Membuat peluang menjadi hebat), buatlah peluang menjadi peluang yang hebat karena kita memang spesialis dalam bidang tersebut, sehingga bisnis kita dapat menjadi "uncomparable"

6. Penemuan "tunggal" (original), dalam hal ini perlu pendaftaan produk ke hak paten, HAKI, atau lainnya untuk memastikan orginalitas hasil.

\section{Pandemi Covid 19}

Pandemi

Indonesia merupakan

pandemi penyakit

2019 (COVID-19)
COVID-19 di bagian dari koronavirus yang sedang 
berlangsung di seluruh dunia. Penyakit ini disebabkan oleh koronavirus sindrom pernapasan akut berat 2 (SARS-CoV-2).

Kasus positif COVID-19 di Indonesia pertama kali dideteksi pada tanggal 2 Maret 2020, ketika dua orang terkonfirmasi tertular dari seorang warga negara Jepang. Pada tanggal 9 April, pandemi sudah menyebar ke 34 provinsi dengan DKI Jakarta, Jawa Barat dan Jawa Tengah sebagai provinsi paling terpapar virus corona di Indonesia.

Sampai tanggal 15 Maret 2021, Indonesia telah melaporkan 1.425.044 kasus positif menempati peringkat pertama terbanyak di Asia Tenggara.Dalam hal angka kematian, Indonesia menempati peringkat ketiga terbanyak di Asia dengan 38.573 kematian.

Namun, angka kematian diperkirakan jauh lebih tinggi dari data yang dilaporkan lantaran tidak dihitungnya kasus kematian dengan gejala COVID-19 akut yang belum dikonfirmasi atau dites. Sementara itu, diumumkan 1.249.947 orang telah sembuh, menyisakan 136.524 kasus yang sedang dirawat.

Pemerintah Indonesia telah menguji 7.781.193 orang dari total 269 juta penduduk, yang berarti hanya sekitar 28.862 orang per satu juta penduduk. Sebagai tanggapan terhadap pandemi, beberapa wilayah telah memberlakukan pembatasan sosial berskala besar (PSBB). Sebagian wilayah tersebut telah mengakhiri masa PSBB dan mulai menerapkan kenormalan baru.

Hal tersebut menunjukan bahwa kasus Covid-19 telah menyebar ke berbagai daerah di Indonesia . selama covid -19 banyak usaha kecil menangah tidak dapat berjualan.Memasuki abad teknologi seperti sekarang ini sangat dirasakan kebutuhan dan pentingnya penggunaan teknologi dalam berbagai bidang salah satunya dalam bidang usaha online. Pandemi covid 19 berimbas pada perekonomian masyarakat, terutama usaha kecil dan menengah yang rentan berkurang pendapatannya.

METODE PELAKSANAAN
Metode kegiatan pengabdian kepada masyarakat ini dibagi menjadi beberapa tahap. Tahap pertama adalah identifikasi masalah yang dilakukan sebagai langkah awal untuk merumuskan apa saja yang akan dijadikan bahan untuk perancangan sistem dan materi pelatihan dalam kegiatan pengabdian kepada masyarakat ini.

Tahap berikutnya yaitu melakukan survei lapangan ke Karang Taruna 022, Jl. Pondok Salak RT 005 / RW 022 Kelurahan Pondok Benda, Kecamatan Pamulang, Kota Tangerang Selatan. Tim pelaksana kemudian melakukan proses wawancara dan diskusi dengan ketua Karang Taruna 022 untuk mengidentifikasi permasalahan yang ada dalam lingkungan anggotanya untuk kemudian merumuskan solusi dan penyelesaiannya serta menentukan keluaran yang diharapkan oleh mitra. Pada tahap ini anggota tim pelaksana berdiskusi menentukan tema dan materi yang akan disampaikan, bahan dan alat yang diperlukan, serta persiapan teknis lainnya yang dibutuhkan untuk kelancaran pelaksanaan kegiatan pengabdian kepada masyarakat ini. Permasalahan yang ditemukan pada Karang Taruna 022 adalah menangkap peluang usaha saat pandemik covid 19.

Metode kegiatan yang digunakan adalah langsung mendatangi Karang Taruna 022, Jl. Pondok Salak RT 005 / RW 022 Kelurahan Pondok Benda, Kecamatan Pamulang, Kota Tangerang Selatan dengan memberikan penyuluhan dan pelatihan pada tanggal 6-8 April 2021. Pelatihan ini bertujuan agar para peserta atau masyarakat di Karang Taruna 022 dapat meningkatkan pemanfaatan teknologi dalam Menangkap Peluang Usaha Saat Pandemi Covid-19.

Pada pelaksanaan Pengabdian Kepada Masyarakat di Karang Taruna ada beberapa teknik yaitu sebagai berikut :

1. Wawancara

Wawancara adalah percakapan dengan maksud tertentu. Percakapan itu dilakukan oleh dua pihak yaitu pewancara (interviewer) yang 
mengajukan pertanyaan dan yang di wawancarai yang memberikan jawaban atas pertanyaan itu (Moleong, 2000:150) Mengenai tujuan wawancara mengemukakan bahwa tujuan wawancara adalah untuk mengetahui apa yang terkandung dalam pikiran dan hati orang lain, bagaimana pandangannya tentang dunia, yaitu halhal yang tidak kita ketahui melalui observasi." Maka tujuan wawancara ini adalah untuk mengetahui apa yang ada dalam pikiran orang lain secara mendalam mengenai pembinaan pada anggota organisasi kepemudaan Karang Taruna Kurbamiharja agar memiliki pribadi yang partisipatif Nasution (1996: 73).

2. Observasi

Pengertian observasi diungkapkan oleh Nazir (1988: 65) yang menyatakan bahwa : "Metode survei (observasi) adalah penyelidikan yang diadakan untuk memperoleh fakta-fakta dari gejala-gejala yang ada dan mencari keterangan-keterangan secara faktual, baik tentang institusi sosial, ekonomi, atau politik dari suatu kelompok ataupun suatu daerah." Sehingga observasi diartikan suatu aktivitas penelitian dalam rangka mengumpulkan data-data yang berkaitan dengan permasalahan dalam penelitian melalui proses pengamatan langsung terhadap objek dilapangan atau lokasi. Metode ini digunakan untuk memperoleh gambaran mengenai pembinaan pada anggota organisasi kepemudaan Karang Taruna agar memiliki pribadi yang partisipatif di masyarakat. Adapun yang menjadi objek daripada observasi ini adalah Karang Taruna 022 ,Jl. Pondok Salak RT 005 / RW 022 Kelurahan Pondok Benda, Kecamatan Pamulang, Kota Tangerang Selatan..

Untuk menunjang
pelaksanaan lancarnya
diperlukanbeberapa alat bantu/media
pembelajaran tertentu, yaitu :
1. LCD (Liquid Crystal Display)
2. Laptop

3. Spidol

4. White board

5. Buku catatan

Tahap terakhir dalam kegiatan pengabdian kepada masyarakat ini yaitu tindak lanjut dari pelaksanaan kegiatan ini. Pada tahap ini dilakukan diskusi atau tanya jawab tentang permasalahan peluang usaha saat pandemik covid 19 di Karang Taruna 022 , Jl. Pondok Salak RT 005 / RW 022 Kelurahan Pondok Benda, Kecamatan Pamulang, Kota Tangerang Selatan.

Kegiatan pengabdian kepada masyarakat ini bertujuan di Karang Taruna 022 mampu dalam pemanfaatan teknologi dalam berbisnis online diantaranya yaitu dapat meningkatkan pengetahuan teknologi dalam bisnis online dan dapat meningkatkan perekonomian di Karang Taruna 022.

\section{HASIL DAN PEMBAHASAN}

\section{Hasil Kegiatan}

Berdasarkan wawancara, tanya jawab dan pengamatan langsung selama kegiatan berlangsung, kegiatan pengabdian pada masyarakat ini memberikan hasil sebagai berikut :

1. Meningkatnya pengetahuan warga khususnya anggota Karang Taruna 022 mengenai menangkap peluang usaha saat pandemic covid 19 .

2. Meningkatnya motivasi warga khususnya anggota Karang Taruna 022 dalam menangkap peluang usaha saat pandemic covid 19.

\section{Faktor Pendukung dan Faktor Penghambat}

Beberapa faktor yang mendukung terlaksananya kegiatan pengabdian pada masyarakat ini adalah besarnya minat dan antusiasme peserta selama kegiatan, sehingga kegiatan berlangsung dengan lancar dan efektif. Sedangkan faktor penghambatnya adalah keterbatasan waktu pelatihan dan fasilitas peralatan yang masih minim.

\section{Pembahasan}


Loyalitas Kreativitas

Aldi Masyarakat Kreatif
P-ISSN 2722-2101, E-ISSN 2722-4201

Program Studi Ekonomi Manajemen Universitas Pamulang

Jurnal LOKABMAS Kreatif Vol.02,No.03.Nov2021Hal.14-23

Email:jurnalkreatif.manajemen@gmail.com
Untuk melaksanakan kegiatan PKM ini digunakan beberapa metode penyuluhan yaitu sebagai berikut :

1. Metode Ceramah $\rightarrow$ Metode yang digunakan dalam penyuluhan ini yaitu penyuluhan dengan memberikan ceramah atau presentasi dengan tema "Menangkap peluang usaha di saat pandemic covid 19"

2. Metode Diskusi Dan Tanya Jawab $\rightarrow$ Setelah sesi pemberian materi selesai, maka dilanjutkan dengan sesi diskusi dengan tanya jawab. Hasil yang didapatkan anggota Karang Taruna 022 antusias untuk bertanya terkait bagaimana cara untuk menangkap usaha saat pandemic Covid-19. Untuk peserta yang aktif dan berani bertanya kami berikan reward berupa cinderamata dari Universitas Pamulang dan sumbangsih dari dosen-dosen Universitas Pamulang.

3. Metode Simulasi $\rightarrow$ Penyuluhan ini juga menggunakan metode simulasi, sehingga peserta langsung dapat mempraktekan apa yang sudah disampaikan. Apabila ada kendala yang dirasakan maka langsung dibantu pada saat pelaksanaan PKM. Simulasi ini penting dilakukan untuk mengetahui seberapa besar tingkat pengetahuan dan ilmu yang diserap oleh anggota Karang Taruna 022 selama penyuluhan.

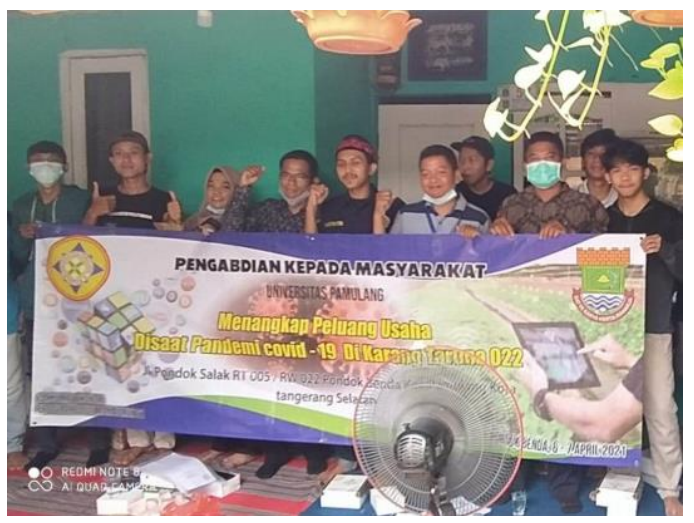

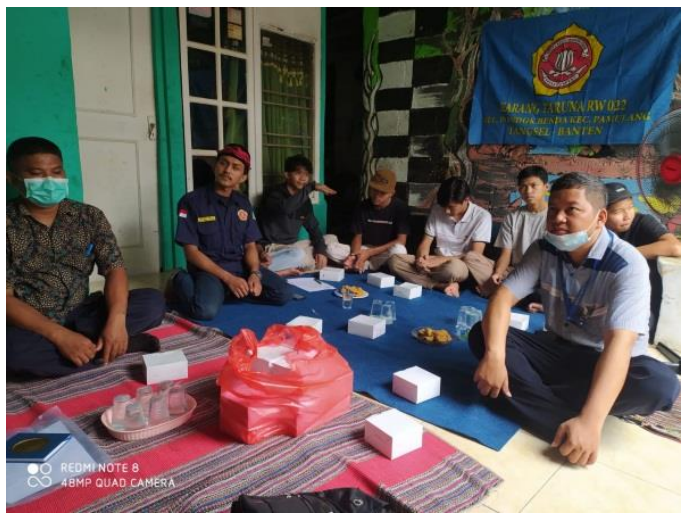
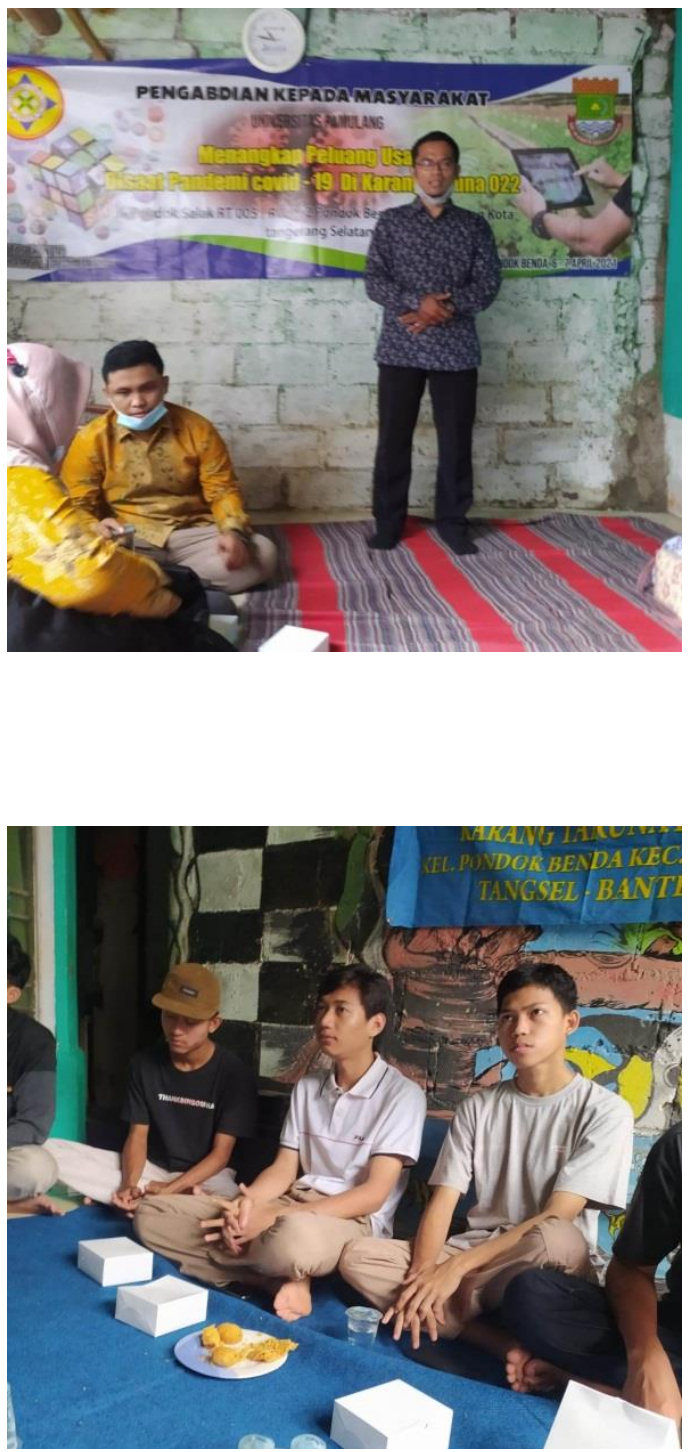


\section{KESIMPULAN DAN SARAN}

\section{Kesimpulan}

Pelaksanaan kegiatan Pengabdian Kepada Masyarakat oleh Lembaga Penelitian dan Pengabdian Masyarakat (LPPM) Universitas Pamulang yang dilakukan oleh dosen-dosen Program Studi Manajemen telah berjalan dengan lancar dan mendapat sambutan positif dan hangat dari tempat pelaksanaan kegiatan PKM di Karang Taruna 022, Jl. Pondok Salak RT 005 / RW 022 Kelurahan Pondok Benda, Kecamatan Pamulang, Kota Tangerang Selatan. Harapan kami selaku dosen dengan adanya kegiatan PKM ini dapat menambah ilmu yang bermanfaat dalam hal sikap disiplin dan tanggung jawab.

Dalam laporan kegiatan PKM ini mungkin banyak kekurangan yang ada, untuk itu kami berharap masukan dan kritikan dalam rangka perbaikan untuk kegiatan PKM selanjutnya.Semoga kegiatan PKM ini dapat bermanfaat bagi masyarakat di lingkungan Karang Taruna 022 dan Lingkungan Universitas Pamulang pada umumnya.

Akhirnya, kami mengucapkan banyak terimakasih kepada seluruh pihak yang telah mendukung dan berkontribusi dalam kegiatan PKM ini dan kami memohon maaf apabila dalam kegiatan PKM ini banyak ditemukan kekurangan dan kesalahan.

\section{Saran}

Berdasarkan hasil kegiatan Pengabdian Kepada Masyarakat yang sudah dilakukan di Karang Taruna 022 , maka kami dari team Dosen Universitas Pamulang memberikan saran yaitu sebagai berikut :

1. Untuk pihak Ketua Karang Taruna 022 lebih menekankan dorongan motivasi kepada anggotanya untuk menangkap peluang usaha saat pandemic Covid-19 saat ini agar anggotanya menjadi lebih berprestasi kelak di kemudian hari.

2. Adanya kontribusi dari pihak Universitas untuk bisa memberikan fasilitas dalam pelayanan kepada masyarakat dalam bentuk sarana dan prasarana.

\section{DAFTAR PUSTAKA}

Ambadar, Jackie, dkk, Mengelola Merek, Jakarta Selatan Yayasan Bina Karsa Mandiri, 2007

Hendro \& Chandra W.W. (2006). Be a Smart and Good Entrepreneur. Jakarta: Erlangga.

Moh. Nazir. 1988. Metodologi Penelitian. Jakarta: Ghalia Indonesia.

Moleong, Lexy J. (2000). Metodologi Penelitian Kuantitatif. Bandung: PT Remaja Rosdakarya.

Nasution (1996: 73). Metode Penelitian Kualitatif Naturalistik. Jakarta : Sinar Grafika.

Pasaribu, V. L. D., Agrasadya, A., Shabrina, N., \& Krisnaldy, K. (2020). Menjadi Enterpreneur Muda Yang Memiliki Jiwa Leadership Untuk Menghadapi Masa Depan. Abdi Laksana: Jurnal Pengabdian Kepada Masyarakat, 1(1).

Pasaribu, V. L. D., Susanti, F., \& Hartuti, E. T. K. (2019). Memotivasi Siswa dan Siswi SMK Letris Indonesia di Dalam Menentukan Pilihan Untuk Melanjutkan Pendidikan Atau Bekerja Setelah Lulus Sekolah. Jurnal Pengabdian Dharma Laksana, 1(2), 161-172.

Pasaribu, V. L. D., Sulaiman, S., Sutiman, S., Thaharudin, T., \& Purnomo, B. Y. (2020). Pengenalan Letak Posyandu Terdekat Dikelurahan Pisangan Dengan Manajemen Pemasaran Revolusi 4.0 Untuk Meningkatkan Pengetahuan Masyarakat Letak Dan Fungsi 
Loyalitas Kreativitas

Abdi Masyarakat Kreatif
P-ISSN 2722-2101, E-ISSN 2722-4201

Program Studi Ekonomi Manajemen Universitas Pamulang

Jurnal LOKABMAS Kreatif Vol.02,No.03.Nov2021Hal.14-23

Email:jurnalkreatif.manajemen@gmail.com
Posyandu Terdekat Pada Kelurahan Pisangan. Dedikasi Pkm, 1(1), 105110.

Pasaribu, V. L. D., Oktrima, B., Prabowo, B., Arianto, N., \& Haryoko, U. B. (2020). Progam Pendampingan Dan Penyelenggaraan Pendidikan Anak Pada Usia Dini Terhadap Prestasi Belajar Dilingkungan Rt $020 \mathrm{Rw}$ 009. Kel Giri Peni. Kec Wates. Yogyakarta. Jurnal Lokabmas Kreatif, 1(1), 71-75.

Pasaribu, V. L. D., Jannah, M., Fazar, M., Putra, S. P., Monalisa, M., \& Sofa, M. (2021). MENINGKATKAN PRODUKTIVITAS USAHA DIMASA PANDEMI PADA IBU PKK RT 004/003 KELURAHAN SAWAH BARU CIPUTAT, TANGERANG SELATAN. Abdi Laksana: Jurnal Pengabdian Kepada Masyarakat,2(2), 295301.

Pasaribu, V. L. D., Yuniati, H. L., Pranata, R., Sembayu, R., Purba, S. M., \& Nurbayani, T. T. A. (2021). MANAJEMEN KEUANGAN UNTUK MENGHADAPI DAN BERTAHAN DI ERA COVID 19. Jurnal Abdimas Tri Dharma Manajemen, 2(2), 12-18.

Pasaribu, V. L. D., Dwiyatni, A., Sabina, C., Ridwan, M., Gunawan, D. D., \& Noviani, B. C. (2021). EVALUASI PENERAPAN 3M DIMASA PANDEMIC COVID 19. Jurnal Abdimas Tri Dharma Manajemen, 2(2), 54-60.

Pasaribu, V. L. D., Syafei, A. N., Farhan, A., Aufaizah, A., Irani, C., \& Firtiayani, S. R. (2021). PENGARUH DISPLIN PROTOKOL KESEHATAN TERHADAP PENCEGAHAN PENULARAN VIRUS COVID19. Jurnal Abdimas Tri Dharma
Manajemen, 2(2), 91-98.

Pasaribu, V. L. D., Septiani, F., Rahayu, S., Lismiatun, L., Arief, M., Juanda, A., ... \& Rahim, R. (2021). Forecast Analysis of Gross Regional Domestic Product based on the Linear Regression Algorithm Technique.

Pasaribu, V. L. D., Priadi, A., Anismadiyah, V., Rahayu, S., \& Maduningtias, L. (2021). PENYULUHAN KREATIF DAN INOVATIF MENINGKATKAN MUTU PRODUKSI UMKM DI DESA BELEGA KABUPATEN GIANYAR. Pro Bono Jurnal Pengabdian Kepada Masyarakat, 1(02).

Pasaribu, V. L. D. (2021). PELATIHAN BERBASIS ONLINE DIERA COVID19. Jurnal Abdimas Tri Dharma Manajemen, 2(3), 26-32.

Pasaribu, V. L. D., \& Setyowati, R. (2021). ADAPTASI KEHIDUPAN NEW NORMAL PADA MASA PANDEMI COVID-19 DIYAYASAN PONDOK PESANTREN DAN PANTI ASUHAN NURUL IKHSAN KECAMATAN SETU, KOTA TANGERANG SELATAN. Jurnal Lokabmas Kreatif: Loyalitas Kreatifitas Abdi Masyarakat Kreatif, 2(2), 82-88.

Priadi, A., Pasaribu, V. L. D., Virby, S., Sairin, S., \& Wardani, W. G. (2020). Penguatan Ekonomi Kreatif Berbasis Sumber Daya Desa Dikelurahan Rempoa. Abdi Laksana: Jurnal Pengabdian Kepada Masyarakat, 1(3), 356-35

Wenti. 2013. Ejournal Pemerintahan Integratif, Eksistensi Karang Taruna dalam Aktivitas Kepemudaan (Studi Kasus di Desa Gunawan Kecamatan Sesayap Kabupaten Tana Tidung). (tidak diterbitkan). 